\title{
PENGARUH DUKUNGAN TEMAN SEBAYA, SUMBER INFORMASI DAN PENGETAHUAN TERHADAP PERILAKU PENCEGAHAN HIV AIDS DIKALANGAN PELAJAR SMKN KALINYAMATAN JEPARA TAHUN 2016
}

\author{
Siti Rohmah \\ Prodi D III Kebidanan, Fakultas Ilmu Kesehatan, Universitas Galuh, Indonesia \\ Email corresponding: rohmah.siti.87@gmail.com \\ (Diterima 25-11-2019; disetujui 18-11-2019; dipublish 26-11-2019)
}

\begin{abstract}
Abstrak
HIV (Human Immunodeficiency Virus) adalah virus yang menyerang system kekebalan tubuh manusia dan melemahkan kemampuan tubuh untuk melawan penyakit.Perilaku pencegahan HIV AIDS pada remaja harus menjadi perhatian bagi pemerintah dan instasi instasi terkait guna untuk meninggkatakan mutu remaja di mata masyarakat. yang penuh gejolak, masa yang penuhdengan berbagai pengenalan dan pertualangan akan hal-hal yang baru termasuk pengalaman berinteraksi dengan lawan jenis sebagai bekal manusia untuk mengisi kehidupan mereka kelak. Sekitar 30\% dari penderita HIV-AIDS ini adalah remaja. Diserangnya usia produktif ini merupakan suatu tantangan yang perlu segera diatasi mengingat usia produktif adalah asset pembangunan bangsa (BKKBN, 2009). Indonesia Negara berkembang di wilayah Asia yang telah digolongkan menjadi Negara dengan tingkat epidemi yang terkonsentrasi atau concentrated level epidemic (CLE) karena memiliki kantong-kantong epidemic dengan prevalensi lebihdari 5\% pada sub populasi beresiko terinfeksi HIV seperti pekerja seks komersial. Tujuan penelitian Mengetahui pengaruh langsung dan tidak langsung serta besaran antara pengetahuan remaja, dukungan teman sebaya dan sumber informasi terhadap perilaku pencegahan HIV AIDS dikalangan pelajar SMKN Kalinyamatan Kabupaten Jepara khususnya tahun 2016. Desain penelitia ndengan metode cross sectional. Pengolahn data dengan Smart Partial Square (PLS).Jumlah sample 100 pelajar SMKN Kalinyamatan.Berdasarkan hasil penelitian bahwa pengaruh pengetahuan terhadap perilaku sebesar $61.22 \%$, pengaruh dukungan teman sebaya terhadap perilaku sebesar $17.06 \%$ dan sumber informasi terhadap pengetahuan sebesar 8,95\%. Disarankan bagi tenaga kesehatan untuk selalu mengadakan romkes guna untuk meningkatkan pengetahaun remaja tentang HIV AIDS.
\end{abstract}

Kata Kunci :Pengetahuan, Dukungan Teman Sebaya,Sumber Informasi

\section{Abstract}

HIV (Human Immunodeficiency Virus) is a virus that attacks the human immune system and weakens the body's ability to fight disease. The behavior of the HIV-AIDS prevention in adolescents should be a concern for the government and relevant agencies instasi to improve the quality of adolescent eyes of society. Adolescence is a turbulent period, a period filled with various recognition and adventures will be new things including the experience of interacting with the opposite sex as a provision for humans to fill their future lives. Approximately 30\% of HIV-AIDS sufferers are teenagers. Attacked this age is a challenge that needs to be addressed immediately productive age is an asset considering the development of the nation Knowing the purpose of research of direct and indirect influence as well as the number of teenagers knowledge, peer support and resources for HIV and AIDS prevention behaviors among students of SMKN kalinyamatan Jepara, especially in 2016. The study design with Cross Sectional Method with Smart Partial Square (PLS). The sample of 100 students of SMKN Kalinyamatan Based on the research that the influence of knowledge about the behavior of $61.22 \%$, the effect of peer support on behavior in 17: 06\% of the knowledge and resources of $8.95 \%$. It is recommended for health workers to always conduct health promotion in order to increase of knowledge of adolescents on HIV AIDS. 


\section{PENDAHULUAN}

Aquired Immune Deficiency syndrome (AIDS) merupakan suatu penyakit yang meresahkan dan mengancam kehidupan masyarakat dan pada saat ini dan telah menyebar ke seluruh dunia dalam bentuk pandemi, karena sampai saat ini belum ada obat untuk menyembuhkanya dan juga belum ada faksin untuk mencegahnya. ${ }^{1}$

Pada tahun 1980 di Kota Fransisco, Amerika Serikat para dokter dikejutkan oleh temuan penyakit yang belum pernah dikenal sebelumnya, yang hanya terdapat pada kaum homoseksual.Penyakit baru ini dalam penelitian selanjutnya disebut sebagaipenyakit AIDS dan penyebaran virus HIV. Para dokter di kota San Fransisco membuat rekomendasi pada pemerintah AS agar kaum homoseksual diawasioleh organisasinya.Namun rekomendasi gagal disebabkan adanya protes dari kaum homoseksual itu sendiri dan warga Amerika lainya dengan alasan pembatasan itu bertentangan dengan HAM. ${ }^{1}$

Tahun 2013 berkaitan dengan perkembangana HIV mengatakan, tingkat penyebaran HIV yang saat ini menginfeksi sekitar 35.3 juta orang di seluruh dunia. ${ }^{2}$

Tingkat penyebaran HIV secara global dan jumlah kematian terkait AIDS telah berkurang berkat perluasan akses perawatan. Jumlah kematian trekait AIDS pada tahun 2012 menurun menjadi 1,6 juta dari 1,7 juta pada tahun 2011 dan puncaknya 2,5 juta pada tahun 2005. Sementara jumlah yang baru terinfeksi penyakit tersebut mencapai 2,3 juta pada 2012, turun dari 2,5 juta pada tahun 2011. Virus human immunodeficiency (HIV) yang menyebabkan AIDS dapat ditularkan melalui darah, air susu ibu dan air mani dalam hubungan seksual, namun dapat dikendalikan dengan campuran obat yang dikenal sebagai perawatan atau terapi antiretrotial. Bahkan untuk masalah anak,jumlah kematian HIV/AIDS dikalangan remaja diseluruh dunia meningkat hingga 50 persen antara tahun 2005 dan 2012 dan menunjukkan tren mengkhawatirkan. Sekitar 71.000 remaja berusia antara 10 dan 19 tahun meninggal dunia karena virus HIV pada tahun 2005. Jumlah itu meningkat menjadi 110.000 jiwa. $^{3}$

Hal ini sangat meresahkan masyarakat umum, padalah remaja adalah kelompok umur yang masih banyak hal yang perluh dilakukan tetapi malah justru meresahakan diri dengan berbagai macam penyakit menular seksual.

Di Indonesia, data dari Ditjen PP dan PL Kemenkes RI Permasalahan HIV dan AIDS menjadi tantangan kesehatan hampir di seluruh dunia, termasuk di Indonesia. Sejak pertama kali ditemukan sampai dengan Pada tahun 2015 diperkirakan terdapat 36,7 juta (34 juta 39,8 juta) orang hidup dengan HIV, meningkat sebanyak 3,4 juta dibandingkan tahun 2010. Sebanyak 2,1 juta di antaranya merupakan kasus baru HIV. Namun, dalam laporan yang sama terjadi penurunan kematian, WHO mencatat sejak AIDS ditemukan hingga akhir 2015 terdapat 34 juta orang meninggal dan di tahun 2015 tercatat sebesar 1,1 juta orang meninggal terkait dengan AIDS, menurun dibandingkan tahun 2010 yang sebesar 1,5 juta kematian.

Di Indonesia, HIV AIDS pertama kali ditemukan di Provinsi Bali pada tahun 1987. Hingga saat ini HIV AIDS sudah menyebar di 407 dari 507 kabupaten/kota (80\%) di seluruh provinsi di Indonesia. Berbagai upaya penanggulangan sudah dilakuakan oleh pemerintah bekerjasama dengan berbagai lembaga di dalam maupun di luar negeri.

Jumlah kasus HIV yang dilaporkan terus meningkat setiap tahun, sementara jumlah AIDS relatif stabil. Hal ini menunjukkan keberhasilan bahwa semakin banyak orang dengan HIV /AIDS (ODHA) yang diketahui statusnya saat masih dalam fase terinfeksi (HIV positif) dan belum masuk dalam stadium AIDS.

Hal ini menunjukkan bahwa masa transisi dari remaja menuju usia dewasa adalah masa krisis yang apabila tidak dibimbing bisa mengarah kepada perilaku yang berisiko. Data Kementerian Kesehatan pada Oktober 2014 menunjukkan, dari Juli sampai dengan September 2014 jumlah infeksi HIV baru yang dilaporkan sebanyak 10.203 kasus, sedangkan jumlah kasus baru AIDS yang dilaporkan sebanyak 1.983 kasus. Dari jumlah tersebut, kalangan remaja adalah salah satu kelompok dengan porsi cukup besar. Persentase kumulatif kasus di kalangan remaja memang tidak sebesar kelompok usia lainnya, namun tetap memerlukan perhatian besar. ${ }^{4}$

Hasil penelitian di peroleh data bahwa $50 \%$ responden berusia 16 tahun, sebanyak $54,8 \%$ mengambil jurusan tata boga dan 
$54,8 \%$ berjenis kelamin perempuan. Hasil penelitian tentang pengetahuan siswa SMKN kalinyamatan jepara tentang HIV/AIDS menunjukkan lebih dari separuh $(90.5 \%)$ memiliki pengetahuan yang baik tentang HIV/AIDS. Dengan memiliki pengetahuan yang tinggi tentang HIV AIDS di harpakan dapat meberikan dampak yang positif yaitu remaja dapat terhindar dai penyakit HIV AIDS. ${ }^{6}$

Data yang diperoleh Lembaga pada 5 tahun terakhir adalah pada tahun 2009 ada 20 kasus, pada tahun 2010 ada 23 kasus pada, tahun 2011 ada 26 kasus, pada tahun 2012 HIV laki-laki 23 perempuan 19 orang AIDS laki-laki 9 perempuan 4, yang meninggal pada tahun 2012 laki-laki 11 orang sedangkan perempuan 5 orang. Tahun 2013 HIV 30 permpuan 21,AIDS laki-laki 9, perempuan 3, yang meninggal laki-laki 9, perempuan 3 orang. Dalam jumlah kasus tahun 2013 terdapat $2(0,02 \%)$ orang remaja yang positif menderita HIV AIDS. Hal ini sangat meresahakan pemerintah kabupaten jepara. Rendahnya pengetahuan dan informasi yang dimilki mengakibatkan remaja cendrung berperilaku buruk Banyaknya jumlah remaja di Kabupaten Jepara dan banyaknya pengaruh dari lingkungan pergaulan pada lingkungan kota. Data tahun 2014 adalah 40 kasus, laki laki 28 dan perempuan 12 orang di anatarnya ada 1 remaja yang berjenis kelamin perempuan. $^{7}$

Tujuan penelitian Mengetahui pengaruh langsung dan tidak langsung serta besaran antara dukungan teman sebaya dan sumber informasi dan pengetahuan remaja, terhadap perilaku pencegahan HIV AIDS dikalangan pelajar SMKN Kalinyamatan Kabupaten Jepara khususnya Tahun 2016.

\section{METODE PENELITIAN}

Penelitian ini menggunakan desain Cross sectional yang dilakukan di SMKN Kalinyamatan Kabupaten Jepara Propinsi Jawa Tengah pada pada bulan Januari-Februari 2016 adalah jumlah indikator dikalikan 5 sampai dengan 10. Karena jumlah indikator yang digunakan penelitian ini adalah 9, maka ukuran sampelnya berada pada rentang 45-90 orang. Selain kriteria tersebut ada kriteria yang lain yang sering digunakan untuk penetapan ukuran sampel, yaitu anatara 100-200. Berdasarkan kedua pertimbangan tersebut maka ukuran sampel dalam penelitian ini ditetapkan sebanyak 100 responden. Teknik pengambilan sampel diambil secara sengaja (pruporse sampling) yaitu sampel diambil berdasarkan kebutuhan penelitian. Kriteria inklusif adalah karaktristik umum sebanyak dari satu populasi target tejangkau yang akan diteliti. Karaktristik inklusi dalam penelitian ini adalah siswa siswi SMKN Kalinyamatan (random sampling) sedangkan kriteria ekskulusi adalah siswa siswi yang tidak ikut mengisi kuisoner karena tidak hadir. ${ }^{8}$

Metode pengukuran baik untuk variabel eksogen maupun endogen yang digunakan dalam penelitian ini menggunakan skala interval, pada sekala sedangkan teknik pengukuranya menggunakan semanticdifferential, yang mempunyai skala 5 point.Pada skala ini sifat positif diberi nilai paling besar dan sifat negatif diberi nilai paling kecil tetap dipertahankan, demikian juga prinsip menggabungkan positif-negatif dan negatif-positif. Alasan pemilihan skala semantic differensialkarena berisikan serangkaian karakteristik bipolar (dua kutub) karenaberisikan serangkaian karakteristik bipolar (dua kutub). ${ }^{8}$

Data yang dikumpulkan meliputi data primer. Data primer diperoleh dengan melakukan pengisian kuesioneroleh responden dengan tingkat pengukuran menggunakan tipeskala diferensial semantik. Maksud dari skala pengukuran untuk mengklarifikasikan variabel yang akan diukur supaya tidak terjadi kesalahan dalam menetapkan analisis data dan langkah penelitian selanjutnya. Teknik pengumpulan data yang digunakan dalam penelitian ini dengan penyebaran angket yang digunakan dalam penelitian ini memakai skala perbedaan semantik (semantik differential scale), skala ini dipergunakan untuk mengukur variabel dukungan teman sebaya,sumber informasi,pengetahuan dan perilaku pencegahan HIV AIDS. ${ }^{9}$

Dalam penelitian ini analisis data menggunakan pendekatan partial least square (PLS) dengan menggunakan software smart PLS. PLS adalah model persamaan struktural (SEM) yang berbaris komponen atau varian (variance). PLS merupakan pendekatan alternatif yang bergeser dari pendekatan SEM berbasis covarience menjadi berbasis varian. SEM yang berbasis kovarian umumnya menguji kausalitas/teori sedangkan PLS lebih bersifat predictive model. Dinyatakan dalam 
World (1985) PLS merupakan metode analisis yang powerfullkarena tidak didasarkan pada asumsi dan tidak harus berdistribusi normal multivariate, (Indikator dengan skala nominal, ordinal, interval sampai rasio) dapat digunakan model yang sama.

Hubungan antarvariabel laten dengan indikatornya atau variabel model analisis jalur semua variabel laten dalam PLS terdiri dari tiga set hubungan: (1) inner model yang spesifikasinya hubungan antar variabel laten (structural model), diukur dengan menggunakan $Q$-Square Predictive Relavance dengan rumus $\mathrm{Q}^{2}=1-\left(1-\mathrm{Ri}^{2}\right)\left(1-\mathrm{Rp}^{2}\right)$, (2) outer model yang menspesifikasikan manifestnya (measurement model), diukur dengan melihat convergentvalidity dan discriminant validity, convergent validity dengan nilai loading 0,5 sampai 0,6 dianggap cukup, untuk jumlah indikator dari variabel laten berkisar 3 sampai 7,sedangkan descriminant validity direkomendasikan nilai AVE lebih besar dari 0,5 dan juga dengan melihat (3) weight relation dimana nilai kasus dari variabel laten tetap disetimasi tanpa kehilangan generalisasi , dapat diasumsikan bahwa variabel laten dan indikator atau manifest variabel diskala zero means dan unit variance sehingga parameter lokasi (parameter konstan) dapat dihilangkan dengan model. Penyajian ini digunakan untuk menyajikan hasil analisis data primer dan data skunder.Selain itu,disajikan pula dalam bentuk diagram untuk mempermudah pembacaan hasil penelitian yangdidapatkan, sedangkan interpretasi data disajikan dalam bentuk narasi sehingga memudahkan pemahaman terhadap hasil penelitian. ${ }^{10}$

Indikator dalam kuisoner Variabel dukungan teman sebaya adalah memberikan informasi,mengajak dan suport,sumber informasi indoaktornya adalah informasi dari media masa,tenaga kesehatan dan dari sekolah,sedangkan perilaku indikatornya adalah upaya menghindari sex bebas,upaya menghindari tato dan tindik dan juga konseling.

Hasil penelitian disajikan dalam bentuk table tekstular.Penyajian data dalam bentuk tabel adalah suatu penyajian sistematik data numerik yang tersusun dalam bentuk kolom dan baris.Penyajian ini dilakukan untuk menyajikan hasil analisis data primer dan sekunder.Selain itu disajikan pula dalam bentuk diagaram untuk mepermudahmembaca hasil penelitian yang didapatkan, sedangkan interpretasi data disajiikan dalam bentuk narasi sehingga mepermudah pemahaman terhadap hasil penelitian.

\section{HASIL PENELITIAN}

Menunjukan bahwa dari 100 responden yang berjenis kelamin perempuan lebih banyak yaitu 55 responden $(53,9 \%)$ sedangkan laki-laki 45 reponden $(44,1 \%)$ dan yang paling banyak berusia 17 tahun yaitu 42 responden $(41,2 \%) 16$ tahun yaitu 30 responden $(29,4 \%), 18$ tahun 28 responden(27,5\%).Data responden dinyatakan dalam beberapa kategori disertai dengan perhitungan nilai range (kisaran), mean (ratarata), danstandar deviasi (penyimpangan). Statistik deskriptif variabel penelitian digunakan untuk memberikan gambaran tentang tanggapan responden mengenai variabelvariabel penelitian yang menunjukkan angka minimum, maksimum, rata-rata serta standar deviasi.

Evaluasi selanjutnya adalah menilai distribusi jawaban responden terhadap variabel-variabel yang diteliti. Pembagian kelas dengan memakai rumus sturgesyaitu :

$$
\begin{aligned}
& \mathrm{K}=(1+3.3 \log \mathrm{N}) \\
& \mathrm{K}=(1+3.3 \log 100) \\
& \mathrm{K}=(1+3.3(2,0)) \\
& \mathrm{K}=7,6=8
\end{aligned}
$$

Data deskriptif sebaran jawaban per variabel memperlihatakan bahwa sebagian besar jawaban responden terhadap variabel perilaku pencegahan HIV AIDS berada pada rentang 28-52 yaitu 29\% atau 29 orang. Jawaban responden pada variablepengetahuan sebagian besar berada pada rentang 19-21 yaitu $39 \%$ atau 39 orang. Untuk variabel dukungan teman sebaya jawaban terbesar berada pada rentang 53-57 yang berjumlah $30 \%$ atau 30 responden, sedangkan variabel sumber informasi sebagaian jawaban responden berada pada rentang 48-52 yaitu $30 \%$ atau 30 responden. Selain itu data responden juga dideskripsikan dengan beberapa kategori disertai dengan perhitungan nilai range (rentang), mean (rata-rata) dan standar deviasi (penyimpangan).

Pada variabel perilaku pencegahan HIV AIDS rentang jawaban resonden berada diantara 33-72 mendekati atau tidak jauh dari kisaran teoritisnya pada nilai tertinggi (15-75) dengan nilai rata-rata 52.37 dan standar deviasi 6.61. Hal ini menunjukkan bahwa perilaku pencegahan HIV AIDS responden berada pada kategori baik.Ini sekaligus menunjukkan 
bahwa sebagian responden sudah melakukan upaya pencegahan terhadap HIV AIDS.

Pada vaiabel pengetahuan, rentang jawaban responden berada antara 10-32 mendekati atau tidak jauh dari kisaran teoristinya pada nilai, dengan nilai rata 17.91 dengan standar devisiensi 2.91. Hal ini mengidikasikan bahwa responden mengganggap pengetahun yang diperoleh cukup baik. Pada variabel dukungan teman sebaya rentang jawaban responden berada diantara 23-72 mendekati atau tidak jauh dari kisaran teoritisnya pada nilai tertinggi (15-75) dengan nilai rata-rata 52.08 dengan standar deviasi 7.80. Hal ini menunjukkan bahwa responden mengaggap dukungan teman sebaya penting dalam hal perilakupencegahan HIV AIDS. Pada variabel sumber informasi rentang jawaban responden berada diantara 33-72 mendekati atau tidak jauh dari kisaran teoritisnya pada nilai tertinggi (15-75) dengan nilai rata-rata 51.88 dengan standar deviasi 6.58. Hal ini menunjukkan bahwa responden mengaggap sumber informasi penting dalam hal perilaku pencegahan HIV AIDS.

Statistik deskriptif variabel penelitian digunakan untuk memberikan gambaran tentang tanggapan responden mengenai variabel-variabel penelitian yangmenunjukkan nilai jawaban minimum maksimum, ratarata,median, dan mode. Pada variabel perilaku pencegahan HIV AIDS nilai jawaban responden terkecil adalah 33 dan terbesar adalah66 dengan rata-rata 52.73 dan terbesar, median 51 dan nilai jawaban terbanyak 51 . Untukvariabel, pengetahuan nilai rata-rata sebesar 17.91 dengan median 18 ,modenya 20, dan jawaban terendahnya 10 dan tertingginya

Berdasarkan tabel $\mathrm{R}$ square tersebut pengetahuan berkonstribusi terhadap dukungan teman sebaya sebesar 0.146242 . NilaiRSquare menyatakan bahwa pengetahuan mampu menjelaskan variabel pengetahuan sebesar $14,6 \%$ dan sebesar $85.4 \%$ dipengaruhi faktor -faktor lain yang tidak diteliti. Sedangakan variabillitas konstrak perilaku pencegahan HIV AIDS sebesar 0.872364 . Nilai $R$ squaremenyatkan bahwa dukungan sumber informasi menjelaskan perilaku pencegahan HIV AIDS sebesar $87,2 \%$ dan $12,3 \%$ dipengaruhi faktor-
24. Sedangkan variabel duklungan teman sebaya jawaban responden terkecilnya adalah 23 dan terbesarnya adalah 66 dengan rata rata 50.08 , medianya 54 dan modenya 51. Variabel sumber informasi nilai jawaban responden terkecil 33 dan yang terbesar 64.Denganrata rata 51.88, median 52 dan mode 51.

Structural Equation Modelling merupakan salah satu analsis multivariate yang dapat menganalisa hubungan variabel secara kompleks.Analisis ini pada umumnya digunakan untuk penelitian-penlitian yang menggunakan banyak variabel.Tekhnik analisa datamenggunakan SEM, dilakukan untuk menjelaskansecara menyeluruh antara variabel yang ada dalam penelitian. SEM digunakan bukan untuk merancang suatu teori, tetapi lebih ditujukan untuk memeriksa danmembenarkan suatu model.Syarat utama menggunakan SEM adalah membangun suatu model hipotesis yang terdiri dari model struktural dan model pengukuran dalam bentuk diagram jalur yang berdasarkan justifikasi teori. SEM merupakan sekumpulan tekhnikstatistik yang memungkinkan pengujian sebuah rangkaian hubungan secara simultan.Structural Equation Modelling merupakan salah satu analsismultivariate yang dapat menganalisa hubungan variabel secara kompleks. Hubungan itu dibangun antara satu atau beberapa variabel independen. Beberapa pengujian confirmatory factor analysis masing-masing variabel laten. Setelah mendapatkan frekuensi dan profil responden, data kemudian diolah dengan program Smart PLS 2.0 dari data yang terkumpul, seperti dibawah ini :

faktor yang lain. Nilai R square. Dapat dilihat pada table berikut yang ada dibawah ini:

Tabel 1 Evaluasi Nilai $R$ Square

\begin{tabular}{|l|c|}
\hline Hasil Uji \\
\hline Variabel & $\boldsymbol{R}$ Square \\
\hline Pengetahuan & 0.146242 \\
\hline Dukungan teman sebaya & \\
\hline Sumber infromasi & \\
\hline $\begin{array}{l}\text { Perilaku pencegahan HIV } \\
\text { AIDS }\end{array}$ & 0.872364 \\
\hline
\end{tabular}

Sumber:SmartPLS diolah 2014

Nilai $Q$-Squarepredictive relevance berfungsi untuk menilai besaran keragaman atau variasidata penelitian terhadap fenomena 
yang kaji. Dilihat dari Nilai $\mathrm{R}$ Square pada table diatas menyatakan bahwa nilai $\mathrm{R}$ square untuk variabel pengetahuan adalah 0.146242 sedangkan variabel perilaku pencegahan HIV AIDS nilai $R$ square adalah 0.872364, sedangkan faktor lain yang mepengaruhi adalah $12,3 \%$. Nilai T statistik direfleksikan terhadap variabelnya $>1,96$, sehingga menunjukan blok indikator berpengaruh positif dan signifikan untuk merefleksikan variabelnya. Setelah evalusai terhadap outer model atau pengukuran, evaluasi pengujian iner model atau model struktural ada 4 variabel yang nilai $T$ statistiknya ada 3 variabel yang > 1,95 sedangkan 1 variabel nilai $\mathrm{T}$ statistiknya lebih kecil dari 1,95 .

Tabel 2 Persentase Pengaruh antar Variabel terhadap Variabel Perilaku Pencegahan HIV AIDS pada model

\begin{tabular}{|l|l|l|l|l|l|l|l|}
\hline Sumber & LV correlation & Direct & Indirect & Total & $\begin{array}{l}\text { Direct } \\
\%\end{array}$ & $\begin{array}{l}\text { Indirect } \\
\%\end{array}$ & $\begin{array}{l}\text { Total } \\
\%\end{array}$ \\
\hline Pengetahuan & 0.859468 & 0.721 & 0,000 & 0.721 & 61.220 & 0,00 & 61,220 \\
\hline $\begin{array}{l}\text { Dukungan } \\
\text { teman sebaya }\end{array}$ & 0.643948 & 0.265 & 0,026 & 0.291 & 17.060 & 0.80 & 17.860 \\
\hline $\begin{array}{l}\text { Sumber } \\
\text { informasi }\end{array}$ & 0.648623 & 0.138 & 0.112 & 0.251 & 8.956 & 3.68 & 12.663 \\
\hline & Total & & & $87.236 \%$ & $4.476 \%$ & 91.713 \\
\hline
\end{tabular}

Sumber :SmartPLS diolah 2011 
Dari tabelPersentase pengaruh antara variabel terhadap variabel perilaku pencegahan HIV AIDS pada model yang ada dibawah ini menyatakan bahwapengetahuan dikatakan berpengaruh langsung dan pengaruh langsungnya adalah 61,220\%dukungan teman sebaya mepunyai dukungan langsung dan tidak langsung terhadap perilaku pencegahan HIV AIDS, pengaruh langsungnya sebesar 17,060 \%dan pengaruh tidak langsungnya adalah $0.80 \%$, sedangkan sumberinformasi juga memiliki pengaruh langsung dan tidak langsung. Pengaruh langsungnya sebesar $8.956 \%$ dan tidak langsungnya sebesar $3,68 \%$.Hal ini menyatakan bahwa vaiabel pengetahuan, dukungan teman sebaya dan sumber informasi mepengaruhi perilaku pencegahan HIV AIDS sebesar87,2\%.

Sehingga dari analisis diatas dapat dibuat persamaan matematik dari variabel perilaku pencegahan HIV AIDS $\boldsymbol{n} \mathbf{1}=\boldsymbol{\xi}_{1} \quad \mathbf{x} \boldsymbol{\gamma}_{3_{+}}$ $\xi_{2 x} \gamma_{2+}$ (Pengetahuan $=$ dukungan teman sebaya $(0,073)+$ sumber informasi $(0,316)+$ factor lain $(0,85) \mathbf{\eta}_{2}=\boldsymbol{\xi}_{1}+\gamma_{24+} \boldsymbol{\eta}_{1 \mathbf{x}} \boldsymbol{\beta}_{+} \boldsymbol{\zeta}_{2 \times} \mathbf{y 1}+\zeta \mathbf{2}$ Perilaku pencegahan HIV AIDS pengetahuan(0.721)+ dukungan teman sebaya $(0,256)+$ sumber informasi $(0,361)+$ faktor lain $(12,8)$.

Penelitian ini memerlukan pemahaman terhadap beberapa aspek baik mengenai metodologi, teori konseptual, maupun teknis dan yang menjadi keterbatasan peneliti. Penelitian ini mempunyai beberapa keterbatasan yaitu penelitian ini menggunakan metode kuantitatif dengan menggunakan alat statistik yang sesuai dengan teori terhadap variabel-variabel yang bersifat kualitatif, dimana ada aspek-aspek variabel dalam penelitian ini tidak dapat didekati dengan metode kuantitatif, sehingga tidak dapat menggali informasi secara objektif. Dalam penelitian ini, untuk mengetahuipengaruh langsung maupun tidak langsung antar variabel, variabel dukungan teman sebaya, sumber informasi dan pengetahuan terhadap variabel perilaku pencegahan HIV AIDS. Penelitian ini merupakan tanggapan responden terhadap suatu variabel penelitian, baik variabel eksogen maupun variabel endogen. Dan tentu saja ada variabel lain yang mempengaruhi yang tidak diteliti dalam penelitian ini, kemungkinan adanya faktor subyektifitas dan ketidak jujuran yang sulit untuk dihindari, sehingga memungkinkan pengukuran tidak seakurat yang diharapkan karena kecenderungan responden untuk memberikanpenilaian yang berlebihantanpa alasan yang objektif. Dan instrumen penelitian ini, kemungkinan belum dapat mengungkap seluruh aspek yang diteliti dan belum sempurna karena keterbatasan penelitian menyusun instrument, sehingga memungkinkan masih terdapat suatu pernyataan dalam instrument yang kurang mengungkap indikator penelitian.

\section{Pengaruh Dukungan Teman Sebaya Terhadap Perilaku Pencegahan HIVAIDS}

Hasil dari penelitian menyatakan bahwa dukungan teman sebaya berpengaruh langsung dan tidak langsungterhadap perilaku. Hasil uji terhadap koefisien parameter antara dukungan teman sebaya terhadap perilaku menunjukan terdapat pengaruh langsung sebesar $17,1 \%$, sedangkan pengaruh tidak langsungnya dukungan teman sebaya melalui pengetahuan sebesar $14,46 \%$. Dukungan teman sebaya berpengaruh positif terhadap perilaku pencegahan HIV AIDS sebesar 2.18 niali T statistinya sebesar 2.594. Nilai $\mathrm{T}$ statistik tersebut berada pada nilai ktitis1,96.Hasil penelitian menunjukan terdapat pengaruh yang positif dari dukungan teman sebaya, sehingga apabila dukungan teman sebaya baik maka akan mepengaruhi perilaku pencegahan HIV AIDS.

Berdasarkan penelitian yang dilakukan ini justru menyatakan bahwa pengaruh teman sebaya terhadap perilaku seksual remaja SMK yang dikutip dari jurnal promosi kesehatan menyatakan bahwa ada hubungan antara perilaku seksual teman sebaya dengan perilaku seksual remaja. Sedangkan nilai $r=0,448$ yang berarti bahwa keeratan hubungannya adalah sedang/cukup. Artinya semakin berisiko perilaku seksual teman sebaya maka perilaku seksual remaja akan semakin berisiko. Berdasarkan hasil analisis jalur diperoleh bahwa pengaruh perilaku seksual teman sebaya secara langsung paling besar mempengaruhi perilaku seksual remaja. Sedangkan pengaruh monitoring parental terhadap perilaku seksual remaja lebih rendah jikadibandingkan dengan perilaku seksual teman sebaya. ${ }^{11}$

Dalam pergaulan remaja, kebutuhan untuk dapat diterima bagi setiap individu merupakan suatu hal yang sangat mutlak sebagai makhluk sosial. Setiap anak yang 
memasuki usia remaja akan dihadapkan pada permasalahan penyesuaian sosial, yang diantaranya adalah problematika pergaulan teman sebaya. Pembentukan sikap, tingkah laku dan perilaku sosial remaja banyak ditentukan oleh pengaruh lingkungan ataupun teman-teman sebaya.Apabila lingkungan sosial itu menfasilitasi atau memberikan peluang terhadap remeja secara positif, maka remaja akan mencapai perkembangan sosial secara matang, dan apabila lingkungan sosial memberikan peluang secara negatif terhadapremaja, maka perkembangan sosial remaja akan terhambat. ${ }^{12}$

Selain lingkungan keluarga, yang ikut mempengaruhi perkembangan seorang individu jika individu tersebut telah berinteraksi dengan individu lain adalah lingkungan sosial. Lingkungan sosial merupakan lingkungantempat dimana seorang individu mulai berinteraksi dengan individu lain diluar anggota keluarga. Lingkungan sosial yang dimaksudkan adalah teman sebaya.Teman sebaya merupakan lingkungan bergaul seorang anak dan melalui interaksi dengan teman sebaya, individu akan berkenalan dan mulai bergaul dengantemantemannya dengan pola perilaku yang berbedabeda, sehingga melalui interaksi inilah masingmasing individu akan saling memahami keinginan-keinginan dan tidak jarang individu akan membentuk kelompok-kelompok jika perilaku teman-temannya tersebut telah dirasa cocok. $^{13}$

Pergaulan teman sebaya mempengaruhi perilaku.Pengaruh tersebut dapat berupa pengaruh positif dan dapat pula berupa pengaruh negatif.Pengaruh positif yang dimaksud adalah ketika individu bersama teman-teman sebayanyamelakukan aktifitas yangbermanfaat seperti membentuk kelompok belajar dan patuh pada norma-norma dalam masyarakat. Sedangkan pengaruh negatif yang dimaksudkan dapat berupa pelanggaran terhadap norma-norma sosial, dan pada lingkungan sekolah berupa pelanggaran terhadap aturan sekolah.Dari teman sebaya remaja menerimaumpan balik mengenai kemampuan mereka.Remaja cenderung untukmengikuti pendapat dari kelompoknya dan menganggap bahwa kelompoknya itu selalu benar.Kecenderungan untuk bergabung dengan teman sebaya didorong oleh keinginan untuk mandiri, sebagaimana yang diungkapkan bahwa melalui hubungan teman sebaya remaja berpikir mandiri, mengambil keputusan sendiri, memerima bahkan menolak pandangan dan nilai yang berasal dari keluarga dan mempelajari pola perilaku yang diterima didalamkelompoknya. ${ }^{14}$

Pengaruh lingkungan diawali dengan pergaulan dengan teman.Pada usia 9-15 tahun hubungan perkawanan merupakan hubungan yang akrabyang diikat oleh minat yang sama, kepentingan bersama, dan saling membagi perasaan, saling tolong menolong untuk memecahkan masalah bersama.

Peran teman sebaya dalam pergaulan remaja menjadi sangat menonjol.Hal ini sejalan dengan meningkatnya minat individu dalam persahabatan serta keikut sertaan dalam kelompok. Kelompok teman sebaya juga menjadi suatu komunitas belajar di mana terjadi pembentukan peran dan standar sosial yang berhubungan dengan pekerjaan dan prestasi .15

Berdasarkan penelitian yang dilakukan tentang peranteman sebaya terhadap perilaku sex pra nikah pada tahun 2013 menyatakan bahwa ada hubungan peran teman sebaya dengan perilaku seksual pranikah pada remaja.Hasil analisis data dengan Chi Square dalam taraf kepercayaan 95\% $(\alpha=5 \%)$, didapatkan hasil nilai $\mathrm{p}$ value sebesar 0,001 untuk peran teman sebaya dengan perilaku seksual pra nikah pada remaja di SMK. ${ }^{16}$

Teman sebaya adalah remaja dengan tingkat usia atau tinggkat kedewasaan yang sama. Teman sebaya merupakan individu atau kelompok satuan fungsi yang berpengaruh pada remaja. Kelompok remaja mempunyai ciri khusus orientasi, nilai-nilai, normadan kesepakatan yang secara khusus hanya berlaku dalam kelompok tersebut . ${ }^{17}$

Teman sebaya memiliki pengaruh langsung terhadap perilaku pencegahaan HIV AIDS karena dengan dukungan teman sebaya dengan cara mepengaruhi kearah yang positif meberikaninformasi yang positif danmeberikan suport yang positifjuga maka akan mepengaruhi perilaku remaja dalam berperilaku yang baik sehingga masalah HIV AIDS dapat dicegah sedini mungkin dengan cara merubah perilaku remaja tersebut. ${ }^{17}$

\section{Pengaruh Dukungan Teman Sebaya Ke Pengetahuan}

Hasil dari penelitian menyatakan bahwa dukungan teman sebaya berpengaruh langsung terhadap perilaku. Hasil uji terhadap koefisien parameter antara dukungan teman sebaya terhadap pengetahuan memiliki nilai sebesar 0.046 dalam penelitian ini meyatakan bahwa 
dukungan teman sebaya tidak mepengaruhi pengetahuan,hal ini tidak sesuai dengan teori yang menyatakan bahwa dukungan teman sebaya berpengaruh terhadap pengetahuan. Nilai $T$ statistik adalah sebesar 0,254 tersebut berada pada nilai ktitis $(<196)$.

Satu fungsi dukungan teman sebaya adalahsebagai informen atau sebagai pemberi informasi.Perkembangan teman sebaya denganpengaruh yang cukup kuat merupakan hal penting dalam masa-masa remaja.

Pada kelompok teman sebaya 1 pertama kalinya remaja menerapkan prj prinsip hidup bersama dan bekerja sama. Jalinan yang kuat itu terbentuk norma, nialinilai dan simbol-simbol tersendiri yang lain dibandingkan dengan apa yang ada di rumah mereka masing-masing.Jadidapat disimpulkan bahwa kelompok teman sebaya sangat berpengaruh terhadap citra diri remaja. Remaja menjadi lebih dekat dengan teman sebayanya, karena mereka menganggap bahwa teman sebaya dapat memahami keinginannya sehingga mereka ingin menghabiskan waktunya dengan teman-temannya.Teman sebaya akan selalau memberi informasi, nasihat dan usulan. Dengan adanya informasiinformasi yang didapat dari teman sebaya dapat meningkatakan pengetahuan remaja tentang HIV AIDS ${ }^{18}$

Dalam penelitian ini menyatkan bahwa tidak ada hubungan yang signifikan antara dukungan teman sebaya terhadap perilaku, hal ini justru tidak sesuai dengan teori yang mengatakan bahwa kelompok teman sebayasangat berepengaruh untuk meningkatkan pengetahuan remaja tentang HIV AIDS. ${ }^{19}$

\section{Pengaruh Sumber Informasi Terhadap} Perilaku Pencegahan HIV AIDS

Hasil dari penelitian menyatakan bahwa sumber informasi berpengaruh langsung dan tidak langsung terhadap perilaku. Hasil uji terhadap koefisien parameter antara sumber informasi terhadap perilaku menujukan terdapat pengaruhlangsung sebesar 17 sedangkan pengaruh tidak langsungnya sumber informasi melalui pengetahuan sebesar 20,3, dan nilai $\mathrm{T}$ statistik sebesar 2,618 signifikan. Nilai $\mathrm{T}$ statistic tersebut berada diatas nilai ktitis $(<1,96)$.

Sumber informasi adalah media atau alatsaluran untuk mendapatkan informasi dan untuk mempermudah penerima pesan-pesan bagi masyarakat atau penerima pesan tersebut. Maka sering orang mengakses informasi tersebut sehinga makin banyak pengetahuan yangdidapat dan sebaliknya seseorang apabila tidak pernah mengakses informasi maka semakin sedikit pengetahuan yang dimilikinya. ${ }^{19}$

Di kemukakan bahwa sumber informasi merupakan faktor pendukung dalam pembentukan perilaku seseorang.Sumber informasi yang berasal dari petugas kesehatan,dari sekolah dan media massa akan mempengaruhi perilaku pencegahan HIV AIDS pada remaja. Sumber informasi kesehatan berasal dari berbagai macam pihak maupun media.Dalam hal penceghan HIV AIDS yang sangat diharapkan pentingnya informasi yang postif mengenai pencegahan HIV AIDS pada remaja. Informasi tersebut bisa didapat pada tenaga kesahatan, pada sekolah dalam hal ini tenaga pengajar maupun teman-teman disekolah dan dari media massa. Dengan semakin banyakanya informasi yang dimiliki oleh remaja akan meningkatkan pengetahauanya sehingga dapat merubah perilakunya. ${ }^{20}$

\section{Pengaruh Sumber Infrormasi Ke} Pengetahuan

Hasil dari penelitian menyatakan bahwa sumber informasi berpengaruh langsung terhadap perilaku. Hasil uji terhadap koefisien parameter anatra sumber informasi terhadap pengetahuan memiliki nilai sebesar 20,4, sumber informasi berpengaruh positif terhadap pengetahuan menyatakan bahwa dukungan teman sebaya mepengaruhi pengetahuan, dan nilai $\mathrm{T}$ statistik signifikan sebesar 2.125pada $a=5 \%$. Nilai $T$ statistictersebut berada pada nilai ktitis $(<1.95)$

Semakin banyak informasi dapat memengaruhi atau menambah pengetahuan seseorang dan dengan pengetahuan menimbulkan kesadaran yang akirnya seseoran akan berperilaku sesuai dengan pengetahuan yang dimilikinya. Sumber informasi jelas sangat berpengaruh dalam perilaku remaja. Hal ini sudah dibuktikan dalam penelitian ini,yangmenyatakan bahwa sumber informasi mepengaruhi pengetahuan remaja tentang HIV AIDS. $^{21}$

Dari hasil penelitian mengenai variabel pengetahuan kisaran jawaban responden antara 15-30 sama dengan kisaran teoritinya pada nilai tertinggi dengan nilai rata-rata17.91 dan standar devisi 2.91 hal lain mengidikasikan pengetahuan lebih yang diperoleh dari responden cukup baik. 
Variabel pengetahuan juga dipengaruhi oleh variabel sumber informasi sebesar 12.46 dan variabel dukungan teman sebaya sebesar 2,81. Dan nilai $T$ statistic sebesar 7,269 signifikan pada $\mathrm{a}=5 \%$. Nilai $\mathrm{T}$ statistic tersebut berada diatas nilai ktitis $(<1,96)$.

Dari hasil penelitian menyatakan bahwa pengetahuan berpengaruh secara langsung terhadap perilaku pencegahan HIV AIDS pada kalangan remaja. Hasil uji koefisien parameter pengaruh langsung pengatahuan terhadap perilaku sebesar. Menurut penelitian yang dilakukan yang diambil dari jurnal kesehatan surya $\mathrm{m}$ Yogyakarta pada tahun 2009 tentang hubu 10 tingkat penegetahuan dan perilaku seksual beresiko pada remajamengatakan bahwa, dari penelitian ini dapat diambil kesimpulan remaja akhir (usia 15 - 20 tahun) di sebuah SMK mempunyai siswa siswinya yang memiliki pengetahuan tentang kesehatan reproduksi yang baik. ${ }^{22}$

Faktor pengetahuan tentang kesehatan reproduksi memberikan pengaruh terhadap perilaku seksual remaja sepertidalam penelitiannya, bahwa adanya pengetahuan tentang manfaat sesuatu hal dapat mempengaruhi niat untuk ikut dalam suatu kegiatan. Sehingga semakin baik pengetahuan responden tentang kesehatan reproduksi maka akan semakin baik pula perilaku seksualnya. ${ }^{23}$

Hal ini sesuai dengan yang diungkapkan bahwa antara pengetahuan dan perilaku sangat berkaitan erat. Pengetahuan akan segi manfaat dan akibat buruk sesuatu hal akan membentuk sikap, kemudian dari sikap itu akan muncul niat. Niat yang selanjutnya akan menentukan apakah kegiatan akan dilakukan atau tidak. Sehingga semakin baik pengetahuan tentang kesehatan reproduksi maka semakin baik perilaku seksualnya.Pengetahuan merupakan hasil tahu, dan ini terjadi setelah orang melakukan penginderaan terhadap suatu objek tertentu.Penginderaan terjadi melalui panca indera manusia yaitu indera penglihatan, pendengaran, penciuman, rasa dan raba.Sebagian besar pengetahuan manusia diperoleh melalui mata dan telinga, dan diperkuat oleh teori yang menyatakan bahwa pengetahuan merupakan faktor predisposisi yang menentukan terbentuknya perilaku seseorang.Pengetahuan merupakan domain yang sangat penting dalam membentuk perilaku seseorang.Dari pengalaman dan penelitian terbukti bahwa perilakudari pada perilaku yang tidak didasari oleh pengetahuan. $^{24}$

Pengetahuan merupakan hasil dari tahu, dan ini terjadi setelah orang melakukan penginderaan terhadap objek tertentu.Penginderaan terjadi melalui penca indera manusia, yakni indera penglihatan, pendengaran, penciuman, rasa dan raba.Pengetahuan ataukognitif merupakan domain yang sangat penting dalam membentuk tindakan seseorang ( overt behaviour). Dari pengalaman dan penelitian terbukti bahwa perilaku yang didasari oleh pengetahuan akan lebih langgeng dari pada perilaku yang tidak didasari oleh pengetahuan. ${ }^{24}$

Menurut survei kesehatan Demografi Indonesai mengatakan bahwa pengetahuan remaja tentangHIV AIDS dikatakan semakin meningkat maka diharapakan akan meningkatkan perlaku pencegahan terhadap HIV AIDS. Dengan mengetahui cara penularan HIV, maka akan lebih mudah melakukan langkah-langkah pencegahannya. Secara mudah pencegahan HIV dapat dilakukan dengan menghindari sex bebas, menghindari tato dan tindik dan melakukan konseling kepada tenaga kesehatan dan juga kepada guru BK dan timpengajar tentang bagaimana pencegahan HIV AIDS itu sendiri.

\section{SIMPULAN DAN SARAN}

Berdasrkan hasil penelitian maka dapat ditemukan sebagai berikut 5 hubungan antara variabel di antaranya 4 berpengaruh signifikan secara positif dan satu hubungan antara variabel tidak signifikan karena berpengaruh secara negatif.Hubungan antara variabel yang signifikan secara positif dengan taraf $a=$ $5 \%(0,05=$ confidence $95 \%)$. Sedangkan hubungan variabel yang signifikan secara negative nilai $a=<5 \%$. Terbentuknya 3 variabel(pengethauan, dukungan teman sebaya dan sumber informasi) yang memiliki pengaruh secara langsung terhadap perilaku pencegahan HIV AIDS.Variabel yang mepunyai pengaruh yang lebih positif adalah variabel pengetahuan terhadap perilaku penceghan HIV AIDS dengan $\mathrm{T}$ hitung sebesar 7.269 diatas nilai $\mathrm{T}$ table (1.96). Presentase pengaruh semua variabel terhadap Perilaku pencegahan HIV AIDS dalam model ini sebesar $87.23 \%$ yang terdiri dari pengaruh langsung sebesar $82.76 \%$ dan pengaruh tidak langsungnya sebesar $4.47 \%$.Nilai Q square (predicitive relevance) sebesar $89.1 \%$. Artinya model secara refresentatif mampu menjelaskan 
keragaman serta dapat mengkaji fenomena yang adadalam penelitian ini.Berdasarkan keterbatasan dalam penelitian ini, adapun saran-saran dalam penelitian selanjutnya adalah penelitian selanjutnya bisa meperluas objek dengan mengambil sampel dari semua sekolah menengah atas yang berada di Kabupaten Lembata, sehingga dapat mengetahui bagaimana perilaku yang dilakukan remaja SMK untuk mencegah HIV AIDS.

Metode penelitian ini juga hendaknya ditindaklanjuti dengan menggunakan metode Kualitatif eksploratory, melalui observasi langsung ketika mengambil data, sel dapat meminimalkan terjadinya bias pen 11 baik aleh rater maupun responden, selain itu model ini perluh ditindaklanjuti dengan mengembangkan instrument serta menambah variabel-variabel yang lainnya yang secara teori mepengaruhi perilaku pencegahan HIV AIDS. Dari hasil penelitian ini dapat dilakukan intervensi secara evaluasi terhadap perilaku pencegahan HIV AIDS dikalangan remaja dan bagi instasi pendidikan dan kesehatan agar selalu meberikan promosi kesehatan secara terus menerus kepada siswa siswi SMA agar mereka dapat lebih memahami tentang masalah HIV AIDS.

\section{DAFTAR PUSTAKA}

1.BKKBN. Penanggulangan Masalah Kesehatan Reproduksi. Jakarta : Direktorat Penanggulangan Masalah Kespro. 2009.

2.WHOAIDS Epidemic Update. Geneva: .[2007,Diakses pada tanggal 15 September,2014]www. Unaids.com

3.UNICEF. Report on the East Asia and Pacific regional Consultation on Children and HIV and AIDS. Bangkok: UNICEF for East Asia and Pacific Regional Office. 2006

4.Ditjen PPM dan PL Kemenkes RI.Statistik KasusHIV/AIDS di Indonesia, Laporan Trinitlan IVtahun 2010.Ditjen PPM \& PL Depkes RI, Jakarta-Indonesia. 2010

5. Herlina. Tesis.Hubungan antara keterpaparan media komunikasi massa dengan pengetahuan remaja tentang HIV AIDS di SMUN 2 Sinjai 2 : 33-

44[2011,Diakses13oktober2014]Lib,ui.ac.id/fil efile/digital/2032031-S-nur

6. Komisi Penanggulangan AIDS Lembata,2013

7. Ghozali, Imam. Structural Equating Modeling Metode Alternatif Partial Least Square (PLS), Undip, Semarang2012.
8.Ridwan M,.Penelitian Tindakan Bimbingan dan Konseling. Alfabeta, Bandung.2012

9.Fajar S. Psikologi Pemuda. Jakarta : Mitra Pustaka Nurani. 2013

10.Hafidz,A.Beberapa Faktor Yang Berhubungan Dengan Perilaku Pekerja Seks Komersial Dalam Pencegahan Penyakit Menular Seksual Di Lokalisasi Gang Sadar Kecamatan Baturaden Kabupaten Banyumas Tahun 2008.http://blogspot.com//html.2009 : Diakses 27 November 2013.

11.Hastutuik. Hubungan Tingkat PengetahuanRemajaTentangKesehatan,

ReproduksiDengan Pengaruh Teman Sebaya TerhadapSeksPraNikah di SMA N 2 Karanganyarkelas

XII.http://blogspot.com//html. 2010 :

12. Notoatmodjo, Soekidjo. Promosi Kesehatan dan Ilmu Prilaku.Jakarta : Rineka Cipta.2007.

13.Soesilowindradini, M. A. Psikologi Perkembangan Masa Remaja. Surabaya: Usaha Nasional. 2005.

14. Singgih D. Gunarso. 1990. Psikologi Untuk Keluarga. Jakarta: Gunung Mulia

15.Suriati. Peran konselor sebaya, Pelayanan kesehatan peduli remaja, Pemanfaatan klinik remaja.Tesis.S2 Ilmu Kesehatan Masyarakat UGM. [2010. Diakses 17september2014]http://etd.ugm.ac.id/index. php?mod=penelitian_detail\&sub=Penelitian Detail\&act $=$ view $\&$ typ $=h t m l \& b u k u \_i d=4729$ 2\&obyek_id=4

16.Handajani, Y. S. (2001) Kehidupan Seksual Remaja Di Daerah Kumuh Perkotaan Jakarta. Majalah Kesehatan Perkotaan No. 2 : 33-44

17.Fajar S..Psikologi Pemuda. Jakarta :Mitra Pustaka Nurani.2013

18. Haris. Beberapa Faktor Yang Berhubungan Dengan Perilaku Pekerja Seks Remaja Dalam Pencegahanseks pra nikah DiSMA 1 Medan [2008, Diakses 27 November 2013.]http://blogspot.com//html. 2009 :

19.Emilia, O. Promosi Kesehatan Dalam Lingkup Reproduksi. Yogyakarta : Pustaka Cendikia Press. 2008.

20. Slamet Santoso. Dinamika Kelompok Sosial. Jakarta: Bumi Aksara.1999.

21.Susilowati.Hubungan Tingkat Pengetahuan dengan Sikap Pekerja Seks Komersial terhadap HIV/AIDS di Pasar Kembang Yogyakarta [2004, Diakses 27 November 2013.].http://blogspot.com//html.

22.Suriati. Peran konselor sebaya, Pelayanan kesehatan peduli remaja, Pemanfaatan klinik 
remaja.Tesis.S2 Ilmu Kesehatan Masyarakat UGM. [2010 diakses 1 november2013]:.http://etd.ugm.ac.id/index.p hp?mod=penelitian_detail\&sub=PenelitianDe tail\&act=view\&typ=html\&buku_id=47292\& obyek_id=4

23. Hutapea. Kesehatan Reproduksi : Sehat dan Ceria. Jakarta : Rineka Cipta. 2003.

24. Green, L.W.Health Program Planning An Educational And Ecological Approach. Emily barrose.2005. 